Article

\title{
Ecological Evidence for the Fitness Trade-Off in Triazine Resistant Chenopodium Album L.: Can We Exploit the Cost of Resistance?
}

\author{
Hossein Ghanizadeh * (1) and Kerry C. Harrington 1 \\ School of Agriculture and Environment, Massey University, PB 11-222, Palmerston North 4442, New Zealand \\ * Correspondence: H.Ghanizadeh@massey.ac.nz; Tel.: +64-6-951-9165
}

Received: 23 August 2019; Accepted: 5 September 2019; Published: 9 September 2019

\begin{abstract}
The alleles responsible for herbicide resistance in weeds can result in a fitness cost within affected plants. Over 200 cases of resistance to triazine herbicides have been confirmed in a wide range of weed species globally. In New Zealand, Chenopodium album L. was the first species reported as resistant to triazines. Several studies have already shown that triazine resistance in weeds is associated with fitness costs. Our current study provides further information about fitness penalties caused by triazine resistance during the vegetative growth phase of $C$. album. Triazine-resistant phenotypes produced less biomass and were shorter than susceptible ones prior to the onset of flowering. At an early stage of growth, triazine-resistant plants had lower photosynthetic efficacy and growth rates than susceptible plants, indicated by lower net assimilation rate (NAR) and relative growth rate (RGR), respectively. However, at a later stage of growth, the resistant plants had greater RGR values than susceptible phenotypes, though there were no significant differences in NAR between triazine-resistant and susceptible plants at this later stage. The triazine-resistant plants had less capacity for vegetative growth than susceptible plants during competition with wheat, indicating less ability to capture resources by triazine-resistant plants under competition. Overall, this study has revealed that the triazine resistance allele caused a substantial fitness cost to $C$. album only at the early phase of vegetative growth stage; thus, the use of crop competition to try managing triazine-resistant C. album plants should occur during this early phase.
\end{abstract}

Keywords: fitness penalty; relative growth rate; herbicide resistance; selection pressure; triazine; vegetative stage

\section{Introduction}

Triazines are broad-spectrum herbicides that target the plastoquinone $\mathrm{B}(\mathrm{PQB})$ binding site located on the photosystem II D1 protein [1]. Triazines have been using routinely in agricultural and non-agricultural systems for many decades due to their effective weed control [2]. However, the first case of resistance to triazines in weeds was reported in the early 1970s in Senecio vulgaris L. [3], and thus far, over 200 cases of resistance to triazines in a wide range of weed species have been reported globally [4]. An altered target site owing to a mutation in the photosystem II protein D1 ( $p s b \mathrm{~A})$ gene is the most typical triazine-resistance mechanism in weed species studied to date [5]. However, there are a few cases of resistance in which a non-target site resistance mechanism, enhanced herbicide detoxification [6], has been reported as the mechanism of resistance to triazines in Abutilon theophrasti Medik. [7] and Amaranthus tuberculatus (Moq.) Sauer [8].

The continuous application of a single herbicide group applies a selection pressure, increasing the resistance allele frequency in a weed population [9]. However, a fitness cost can be associated with the selected resistance allele(s) [10]. The cost associated with the resistance mutation(s) in the absence of a 
xenobiotic is a common concept in evolutionary ecology [11]. Resistance mutations can be beneficial to plants in presence of certain xenobiotics, but these mutations often have pleotropic effects in the absence of the xenobiotic [12]. Fitness costs have been recorded in some cases of resistance to herbicides such as with Acetyl-CoA carboxylase (ACCase)-inhibitors [13], glyphosate [14], and dicamba [15]. However, in some cases of resistance to herbicides such as for acetolactate synthase (ALS)-inhibiting herbicides with a target-site resistance mechanism, no fitness costs have been found in resistant phenotypes [16]. Fitness costs in herbicide-resistant weeds can be manifested at different stages in the life history of affected plants, such as reduced germination and emergence, reduced growth and development, or reduced reproductive output [10]. Several studies have indicated that triazine resistance in weeds is associated with fitness costs (reviewed by Vila-Aiub et al. [10]). The first study of fitness penalties in triazine-resistant weeds was conducted by Conard and Radosevich [17]. They found triazine-susceptible phenotypes of Senecio vulgaris and Amaranthus retroflexus L. produced more dry matter than triazine-resistant ones. Holt et al. [18] reported that triazine-resistant individuals of Senecio vulgaris had a lower photosynthetic capacity than susceptible ones. Reduced vegetative growth and reproductive outputs during intra-species competition have also been recorded for triazine-resistant phenotypes of Amaranthus retroflexus and Amaranthus powellii Wats. [19], and Senecio vulgaris [20]. Kremer and Kropff [21] reported that triazine-resistant Solanum nigrum L. produced almost 25\% less biomass than a triazine-susceptible phenotype at varying light intensities. However, Frenkel et al. [22] noted that triazine-resistant phenotypes of Brachypodium hybridum only had a lower shoot dry mass than susceptible ones under low light conditions. They also found that triazine-resistant phenotypes of Brachypodium hybridum had a lower nitrogen use efficiency than susceptible plants.

Chenopodium album L. is a troublesome weed species in many cropping systems worldwide [23-26]. In New Zealand, C. album was first reported resistant to triazines in the early 1980s [27], the first case of herbicide resistance in this country. Some populations of $C$. album populations have since evolved multiple-resistance in New Zealand to herbicides such as dicamba and picloram in addition to triazines [26,28-30]. There are only a few studies regarding fitness cost in triazine-resistant C. album. For instance, Warwick and Black [31] found that triazine-resistant C. album, when compared with susceptible plants, produced less vegetative and reproductive biomass, and the triazine-resistant phenotype was inferior during competition with the susceptible phenotype. Parks et al. [32] also recorded lower vegetative biomass and leaf area for triazine-resistant phenotypes of $C$. album than the susceptible one. These two studies mainly focused on costs involved in biomass production of triazine-resistant $C$. album; thus, the detailed pleiotropic effects of triazine resistance on eco-physiological characteristics of the vegetative growth phase of $C$. album have not been investigated. It was unclear if the pleiotropic fitness costs conferred by triazine resistance are expressed throughout the vegetative stage of C. album growth. In addition, the ecological implications of any fitness costs of resistance for triazine-resistant $C$. album are unknown in the absence of herbicides. In this research, we compared the eco-physiological effects of resistance to triazines in the early versus later vegetative growth stages in C. album when no triazine herbicide had been applied. Preliminary investigations suggested a fitness cost associated with the $C$. album phenotypes we studied was possibly caused by the most common mutation responsible for resistance to atrazine, the Ser-264-Gly mutation [33]. We also investigated the ecological implications of the cost of triazine resistance by using a neighbouring plant (inter-specific competition) experiment.

\section{Materials and Methods}

\subsection{Plant Materials}

For this research, two populations of each C. album phenotype were used, namely triazine-resistant populations, TR1 and TR2, and triazine-susceptible populations, TS1 and TS2, as suggested by Vila-Aiub et al. [10]. Seeds for each population were obtained by growing a group of plants $(n=10)$ from each population separated from the plants of other populations. At maturity, the seeds were 
harvested separately for each population and stored at $5{ }^{\circ} \mathrm{C}$ until required in the experiments described below.

\subsection{Growth Analysis Experiment}

The C. album seeds were germinated on Steel Blue Seed Germination Blotter papers (Anchor Paper, Saint Paul, MN, USA) saturated with $0.2 \% \mathrm{KNO}_{3}$ (potassium nitrate) as described by Ghanizadeh et al. [28]. The germinated seeds were transplanted into pots ( $\mathrm{PB} \frac{3}{4}$ polyethylene planter bags, approximately $0.45 \mathrm{~L}$ capacity) filled with $20 \%$ Pacific Pumice $(7 \mathrm{~mm}), 30 \%$ fibre, $50 \%$ bark and slow release fertiliser (Woodace, PA, USA). The fertiliser contained $18 \%$ nitrogen, $5 \%$ phosphate, $10 \%$ potassium, $0.5 \%$ magnesium, $3.2 \%$ sulfur, $1.6 \%$ iron, $0.3 \%$ manganese and $2 \%$ chlorine. The pots were kept in a glasshouse with automated capillary irrigation, using a spacing of $10 \mathrm{~cm}$ between each pot. To prevent immediate plant flowering, day length was maintained at $14 \mathrm{~h}$ using nine $1000 \mathrm{~W}$ LED lamps. At 15, 35 and 55 days after transplanting (DAT), eight plants from each population were harvested after measuring their height. Once plants reached the early flowering stage, the final height was measured for both phenotypes, though this timing differed between phenotypes due to differences in rate of development (see results). Harvested plants were split into leaf and shoot and root. The roots of harvested plants were washed free of potting mix under laboratory tap water. Each harvested plant had its leaf area (LA) measured using a digital LA meter (LiCor model-3100; Lincoln, NE, USA). Then, the harvested material (i.e., leaves, stem and root) from each plant was oven dried separately for $48 \mathrm{~h}$ at $80^{\circ} \mathrm{C}$, then weighed. Relative growth rate (RGR) and its components, net assimilation rate (NAR) and leaf area ratio (LAR), were estimated for the populations using the techniques of Hunt et al. [34]. The pots for each population were arranged in a completely randomised design with 10 replicates for each time course, and the experiment was conducted twice. The relative humidity in the glasshouse generally remained at $55-65 \%$, and the average maximum/minimum daily temperatures were $24.3 / 12.8^{\circ} \mathrm{C}$ and $23.8 / 14.3^{\circ} \mathrm{C}$ for the first (March-April) and second (August-October) experiments, respectively.

\subsection{Neighbouring Plant Competition Experiment}

The competitive performance of triazine-resistant and triazine-susceptible phenotypes was evaluated under competition with a neighbouring crop [35]. This experiment was used to evaluate the ecological cost associated with triazine resistance in C. album. In this experiment, the vegetative performance of the triazine-resistant and triazine-susceptible phenotypes was assessed when both phenotypes were subjected to increasing density of interspersed neighbouring crop plants, using wheat (Triticum aestivum L. cv. Duchess) in a size symmetric competition experiment as described by Vila-Aiub et al. [36]. The wheat densities used in this research were spatially arranged to provide densities equivalent to $0,20,80,200$ and 400 plants $\mathrm{m}^{-2}$. The wheat seeds were germinated by placing them $(n=100)$ between two damp paper towels. The moistened towels were then rolled and placed in a plastic bag at $20^{\circ} \mathrm{C}$ for 6 days. The wheat seedlings were then transplanted to pots $(25 \mathrm{~cm}$ diameter) containing the potting mix and fertiliser described above, using a spacing of $20 \mathrm{~cm}$ between each pot. The C. album seeds were germinated, and transplanted into pots when wheat plants were at the 2-3-leaf stage. The density of C. album plants was equivalent to 20 plants $\mathrm{m}^{-2}$. This experiment used a completely randomised design with each treatment four times. Any possible location effects were minimised by randomly rearranging the pots. At 35 days after transplanting the C. album seedlings, variation in light caused by the wheat was determined using a quantum PAR meter to quantify photosynthetically active radiation (PAR) intercepted by the top of the C. album (the target plant) canopy in response to each wheat density combination. The above-ground biomass of wheat and C. album was harvested at 60 days after transplanting C. album once the height of C. album plants was measured. The leaf area of the target plants was evaluated next using a digital LA meter (described above). The above-ground material was then weighed once it had been oven dried at $80^{\circ} \mathrm{C}$ for $72 \mathrm{~h}$. 


\subsection{Statistical Analysis}

All of the growth analysis experiment data were checked for normality, and any data that were not normally distributed were either square-root or $\log _{\mathrm{e}}$ transformed prior to statistical analysis. Where the assumptions of ANOVA were not violated, data were analysed using a one-way ANOVA and the means were separated using a Fisher protected test at $5 \%$ probability. The nonparametric Kruskal-Wallis $\mathrm{H}$ Test was used to analyse data that failed to meet the ANOVA assumptions following transformation. All statistical analyses were performed using SPSS 22.0. The response of the target plants to increasing density of neighbouring plants was evaluated using a hyperbolic non-linear regression model [35]:

$$
F=\frac{t}{1+b x}
$$

where $F$ represented the evaluated trait (e.g., biomass) of the target plants in response to the associated density of the neighbouring plants, $x$ represented the density of neighbouring plants, $t$ was the evaluated trait of the target plants when the density of neighbouring plants was zero and $b$ was the slope of the regression. In order to meet regression analysis assumptions, the data from the evaluated trait (i.e., biomass, leaf area and height) were either $\log [x]$ or $\log [x+1]$ transformed. The regression model was fitted using the $\mathrm{R}$ statistical program with its $n l s 2$ package [37]. The estimated values for parameter $b$ were statistically compared between triazine-resistant and triazine-susceptible phenotypes using a one-way ANOVA.

\section{Results}

\subsection{Growth Analysis}

By 35 DAT, the triazine-susceptible phenotypes, TS1 and TS2, had significantly greater leaf area and biomass than the triazine-resistant ones, TR1 and TR2, for both experiments (Table 1). However, by $55 \mathrm{DAT}$, although the biomass of the triazine-susceptible phenotypes was still significantly greater than for the triazine-resistant plants, differences in leaf area between the phenotypes were not significant (Table 2). 
Table 1. Leaf area, total dry weight, relative growth rate (RGR), net assimilation rate (NAR) and leaf area ratio (LAR) of triazine-susceptible (TS1 and TS2) and triazine-resistant (TR1 and TR2) populations of C. album harvested at 35 DAT in the first and second experiments.

\begin{tabular}{|c|c|c|c|c|c|}
\hline & \multicolumn{5}{|c|}{ First Experiment } \\
\hline & TS1 & TS2 & TR1 & TR2 & \\
\hline & & & & & $p$ values \\
\hline Dry weight (mg plant $\left.{ }^{-1}\right) *$ & $2709.2 \mathrm{a}$ & $2638.5 \mathrm{a}$ & $1416.7 \mathrm{~b}$ & $1456.9 \mathrm{~b}$ & 0.0001 \\
\hline Leaf area $\left(\mathrm{cm}^{-2} \text { plant }^{-1}\right)^{*}$ & $232.7 \mathrm{a}$ & $196.3 \mathrm{a}$ & $128.0 \mathrm{~b}$ & $122.2 \mathrm{~b}$ & 0.0001 \\
\hline $\operatorname{RGR}\left(m g \mathrm{mg}^{-1} \mathrm{~d}^{-1}\right) *$ & $0.149 \mathrm{a}$ & $0.147 \mathrm{a}$ & $0.120 \mathrm{~b}$ & $0.124 \mathrm{~b}$ & 0.0001 \\
\hline $\operatorname{NAR}\left(\mathrm{mg} \mathrm{cm}^{-2} \mathrm{~d}^{-1}\right) *$ & $1.311 \mathrm{ab}$ & $1.446 \mathrm{a}$ & $1.044 \mathrm{~b}$ & $1.146 \mathrm{~b}$ & 0.0480 \\
\hline \multirow[t]{4}{*}{$\operatorname{LAR}\left(\mathrm{cm}^{2} \mathrm{mg}^{-1}\right) *$} & 0.162 & 0.153 & 0.149 & 0.145 & 0.8150 \\
\hline & \multicolumn{5}{|c|}{ Second Experiment } \\
\hline & TS1 & TS2 & TR1 & TR2 & \\
\hline & & & & & $p$ values \\
\hline Dry weight $\left(\mathrm{mg}\right.$ plant $\left.{ }^{-1}\right) \ddagger$ & $3076.9 a$ & $2738.5 \mathrm{a}$ & $1567.8 \mathrm{~b}$ & $1517.0 \mathrm{~b}$ & 0.0001 \\
\hline Leaf area $\left(\mathrm{cm}^{-2}\right.$ plant $\left.^{-1}\right) *$ & $177.9 \mathrm{a}$ & $173.2 \mathrm{a}$ & $131.5 \mathrm{~b}$ & $137.0 \mathrm{~b}$ & 0.012 \\
\hline $\operatorname{RGR}\left(\mathrm{mg} \mathrm{mg}^{-1} \mathrm{~d}^{-1}\right) \ddagger$ & $0.147 \mathrm{a}$ & $0.144 \mathrm{a}$ & $0.131 \mathrm{~b}$ & $0.127 \mathrm{~b}$ & 0.004 \\
\hline $\operatorname{NAR}\left(\mathrm{mg} \mathrm{cm}^{-2} \mathrm{~d}^{-1}\right) \ddagger$ & $1.736 \mathrm{a}$ & $1.636 \mathrm{a}$ & $1.164 \mathrm{~b}$ & $1.108 \mathrm{~b}$ & 0.0001 \\
\hline $\operatorname{LAR}\left(\mathrm{cm}^{2} \mathrm{mg}^{-1}\right) \ddagger$ & 0.134 & 0.130 & 0.152 & 0.146 & 0.335 \\
\hline
\end{tabular}

* Individual growth traits were analysed using a Kruskal-Wallis test. Different letters indicate significant differences between mean values within rows for each experiment at $5 \%$ probability. $\ddagger$ Individual growth traits were analysed using a one-way ANOVA test. Different letters indicate significant differences between mean values within rows for each experiment according to Fisher's protected tests at $5 \%$ probability.

During the early vegetative stage of growth (15-35 DAT), the TS phenotypes had an average RGR that was $17 \%$ and $12 \%$ higher than the TR phenotypes in the first and second experiments, respectively (Table 1). Likewise, the triazine-susceptible phenotypes had greater net assimilation rates (NAR) than the triazine-resistant phenotypes. However, no significant differences were recorded between the phenotypes in leaf area ratios (LAR). Similar results were obtained in the second experiment (Table 1). 
Table 2. Leaf area, total dry weight, relative growth rate (RGR), net assimilation rate (NAR) and leaf area ratio (LAR) of triazine-susceptible (TS1 and TS2) and triazine-resistant (TR1 and TR2) populations of C. album harvested at 55 DAT in the first and second experiments.

\begin{tabular}{|c|c|c|c|c|c|}
\hline & \multicolumn{5}{|c|}{ First Experiment } \\
\hline & TS1 & TS2 & TR1 & TR2 & \\
\hline & & & & & $p$ values \\
\hline Dry weight $\left(\mathrm{mg}\right.$ plant $\left.{ }^{-1}\right) \ddagger$ & $6517.5 \mathrm{a}$ & $6315.5 \mathrm{a}$ & $5261.1 \mathrm{~b}$ & $5321.2 \mathrm{~b}$ & 0.006 \\
\hline Leaf area $\left(\mathrm{cm}^{-2}\right.$ plant $\left.^{-1}\right) \ddagger$ & 188.4 & 183.2 & 199.2 & 198.3 & 0.897 \\
\hline $\operatorname{RGR}\left(m g \mathrm{mg}^{-1} \mathrm{~d}^{-1}\right) *$ & $0.044 \mathrm{~b}$ & $0.045 \mathrm{~b}$ & $0.057 \mathrm{a}$ & $0.056 \mathrm{a}$ & 0.014 \\
\hline $\operatorname{NAR}\left(\mathrm{mg} \mathrm{cm}^{-2} \mathrm{~d}^{-1}\right) \ddagger$ & $0.865 \mathrm{~b}$ & $1.087 \mathrm{ab}$ & $1.096 \mathrm{ab}$ & $1.154 \mathrm{a}$ & 0.12 \\
\hline \multirow[t]{4}{*}{$\operatorname{LAR}\left(\mathrm{cm}^{2} \mathrm{mg}^{-1}\right) \ddagger$} & 0.064 & 0.050 & 0.062 & 0.058 & 0.179 \\
\hline & \multicolumn{5}{|c|}{ Second Experiment } \\
\hline & TS1 & TS2 & TR1 & TR2 & \\
\hline & & & & & $p$ values \\
\hline Dry weight $\left(\right.$ mg plant $\left.^{-1}\right) \ddagger$ & 6753.6 a & $6817.3 \mathrm{a}$ & $5255.6 \mathrm{~b}$ & $5370.1 \mathrm{~b}$ & 0.0001 \\
\hline Leaf area $\left(\mathrm{cm}^{-2} \text { plant }^{-1}\right)^{*}$ & 184.2 & 191.8 & 215.1 & 207.1 & 0.49 \\
\hline $\operatorname{RGR}\left(\mathrm{mg} \mathrm{mg}^{-1} \mathrm{~d}^{-1}\right) \ddagger$ & $0.048 \mathrm{bc}$ & $0.046 \mathrm{c}$ & $0.061 \mathrm{a}$ & $0.057 \mathrm{ab}$ & 0.012 \\
\hline $\operatorname{NAR}\left(\mathrm{mg} \mathrm{cm}^{-2} \mathrm{~d}^{-1}\right) \ddagger$ & 1.145 & 1.131 & 1.046 & 1.015 & 0.577 \\
\hline $\operatorname{LAR}\left(\mathrm{cm}^{2} \mathrm{mg}^{-1}\right) \ddagger$ & $0.047 \mathrm{~b}$ & $0.048 \mathrm{~b}$ & $0.070 \mathrm{a}$ & $0.066 \mathrm{a}$ & 0.0001 \\
\hline
\end{tabular}

* Individual growth traits were analysed using a Kruskal-Wallis test. Different letters indicate significant differences between mean values within rows for each experiment at $5 \%$ probability. $¥$ Individual growth traits were analysed using a one-way ANOVA test. Different letters indicate significant differences between mean values within rows for each experiment according to Fisher's protected tests at $5 \%$ probability.

In the later vegetative stage of growth (35-55 DAT), these trends for the growth parameters had changed (Table 2). In both experiments, the triazine-resistant phenotypes had greater RGR values than the triazine-susceptible ones at 55 DAT. Additionally, there were no significant differences in the NAR values between the phenotypes at 55 DAT (Table 2). Triazine-resistant phenotypes were significantly shorter than triazine-susceptible plants at 35 and 55 DAT in both experiments (Table 3). Although the final height measured at the start of the flowering stage was not significantly different between phenotypes, the susceptible phenotypes reached this stage at 65 and 63 DAT, whereas the final plant height for the resistant phenotype was measured at 90 and 93 DAT in the first and second experiments, respectively.

Table 3. The height of triazine-susceptible (TS1 and TS2) and triazine-resistant (TR1 and TR2) populations of $C$. album measured at three different time courses.

\begin{tabular}{ccccccc}
\hline & \multicolumn{5}{c}{ Height $(\mathbf{c m})$} \\
\cline { 2 - 7 } & \multicolumn{3}{c}{ First Experiment } & \multicolumn{3}{c}{ Second Experiment } \\
\cline { 2 - 7 } & 35 DAT $\ddagger$ & 55 DAT & Final Height * & 35 DAT & 55 DAT & Final Height * \\
\hline TS1 & $55.8 \mathrm{a}$ & $126.5 \mathrm{a}$ & 140.6 & $51.9 \mathrm{a}$ & $122.8 \mathrm{a}$ & 138.8 \\
TS2 & $51.8 \mathrm{~b}$ & $138.4 \mathrm{a}$ & 136.7 & $54.3 \mathrm{a}$ & $127.0 \mathrm{a}$ & 134.7 \\
TR1 & $29.7 \mathrm{c}$ & $87.0 \mathrm{~b}$ & 135.3 & $27.4 \mathrm{~b}$ & $90.9 \mathrm{~b}$ & 133.1 \\
TR2 & $28.5 \mathrm{c}$ & $85.8 \mathrm{~b}$ & 135.6 & $25.0 \mathrm{~b}$ & $88.7 \mathrm{~b}$ & 134.9 \\
\hline$p$ values & 0.0001 & 0.0001 & 0.051 & 0.0001 & 0.0001 & 0.062 \\
\hline
\end{tabular}

$p$ values were obtained from one-way ANOVA tests on height. Different letters indicate significant differences between mean values within columns for each experiment according to Fisher's protected tests at $5 \%$ probability. $\ddagger$ Days after transplanting. ${ }^{*}$ The final height was measured at the flowering stage.

\subsection{Neighbour Competition Experiments}

Exposure to increasing densities of neighbouring wheat competitors was used to assess the relative competitive ability of triazine-resistant and susceptible phenotypes. The hyperbolic model predicted 
well the response of the evaluated traits (biomass production, leaf area and height) of the target plants at the given density of neighbouring plants as shown by significant goodness of fit $(p<0.0001)$ and coefficients of determination $\left(R^{2}=0.84-0.99\right)$. Thus, estimates of parameter $b$ of the hyperbolic model for each phenotype were used to evaluate the competitive ability of each phenotype (Table 4 ).

Table 4. An evaluation of competitive responses (biomass production, leaf area and height) by triazine-susceptible (TS1 and TS2) and triazine-resistant (TR1 and TR2) populations of C. album among neighbouring wheat plants. Values represent the mean estimate of parameter $b$ derived from a hyperbolic model.

\begin{tabular}{ccccccc}
\hline \multirow{2}{*}{ Population } & \multicolumn{3}{c}{ First Experiment } & \multicolumn{3}{c}{ Second Experiment } \\
\cline { 2 - 6 } & Biomass & Height & Leaf Area & Biomass & Height & Leaf Area \\
\hline TS1 & $0.0064 \mathrm{~b}$ & $0.0036 \mathrm{~b}$ & $0.0052 \mathrm{~b}$ & $0.0046 \mathrm{~b}$ & $0.0039 \mathrm{bc}$ & $0.0075 \mathrm{c}$ \\
TS2 & $0.0059 \mathrm{c}$ & $0.0045 \mathrm{~b}$ & $0.0041 \mathrm{~b}$ & $0.0047 \mathrm{~b}$ & $0.0035 \mathrm{c}$ & $0.0088 \mathrm{bc}$ \\
TR1 & $0.0131 \mathrm{a}$ & $0.0093 \mathrm{a}$ & $0.0111 \mathrm{a}$ & $0.0093 \mathrm{a}$ & $0.0056 \mathrm{ab}$ & $0.0111 \mathrm{ab}$ \\
TR2 & $0.0128 \mathrm{a}$ & $0.0074 \mathrm{a}$ & $0.0137 \mathrm{a}$ & $0.0103 \mathrm{a}$ & $0.0073 \mathrm{a}$ & $0.0122 \mathrm{a}$ \\
\hline$p$ values & 0.0001 & 0.0034 & 0.0015 & 0.0006 & 0.0049 & 0.05 \\
\hline
\end{tabular}

The mean values of parameter $b$ were statistically compared between phenotypes using a one-way ANOVA, and the means were compared using Fisher's protected tests at $5 \%$ probability. Different letters indicate significant differences between mean values within columns for each experiment.

Theoretically, the target plants are expected to show best performance in a neighbouring plant competition experiment when the density of the neighbouring crop equals zero. Increasing the density of the neighbouring plants should decrease the performance of the target plants [35]. Parameter $b$ in the hyperbolic model represents competition performance of the target plants [35]. Greater values of parameter $b$ indicate that the target plants have a poorer ability to compete at a given neighbouring plant density than if parameter $b$ is lower.

Figure 1a,b illustrate the decrease in light at the top of the canopy of both phenotypes as the density of wheat increased. The results of the neighbouring plant experiments revealed the biomass, height and leaf area of both triazine-resistant and susceptible phenotypes decreased with increasing densities of wheat. However, a weaker performance was observed for the triazine-resistant phenotypes compared to the triazine-susceptible ones according to the significantly larger parameter $b$ values for the above-ground biomass of triazine-resistant phenotypes under competition (Table 4). This implies that the competitive effects imposed by wheat plants adversely affected the triazine-resistant plants more than susceptible ones. As well as the greater reduction in the above-ground biomass measured for the triazine-resistant phenotypes, there was also a significant decrease in height and leaf area of $C$. album plants as densities of wheat plants increased. This could be seen by the significantly greater parameter $b$ values for height and leaf area reduction in response to increasing wheat densities for the triazine-resistant compared to the triazine-susceptible phenotypes (Table 4). These results clearly showed that the triazine-resistant phenotypes were weaker competitors compared to the triazine-susceptible phenotypes in the neighbouring plant experiments. 

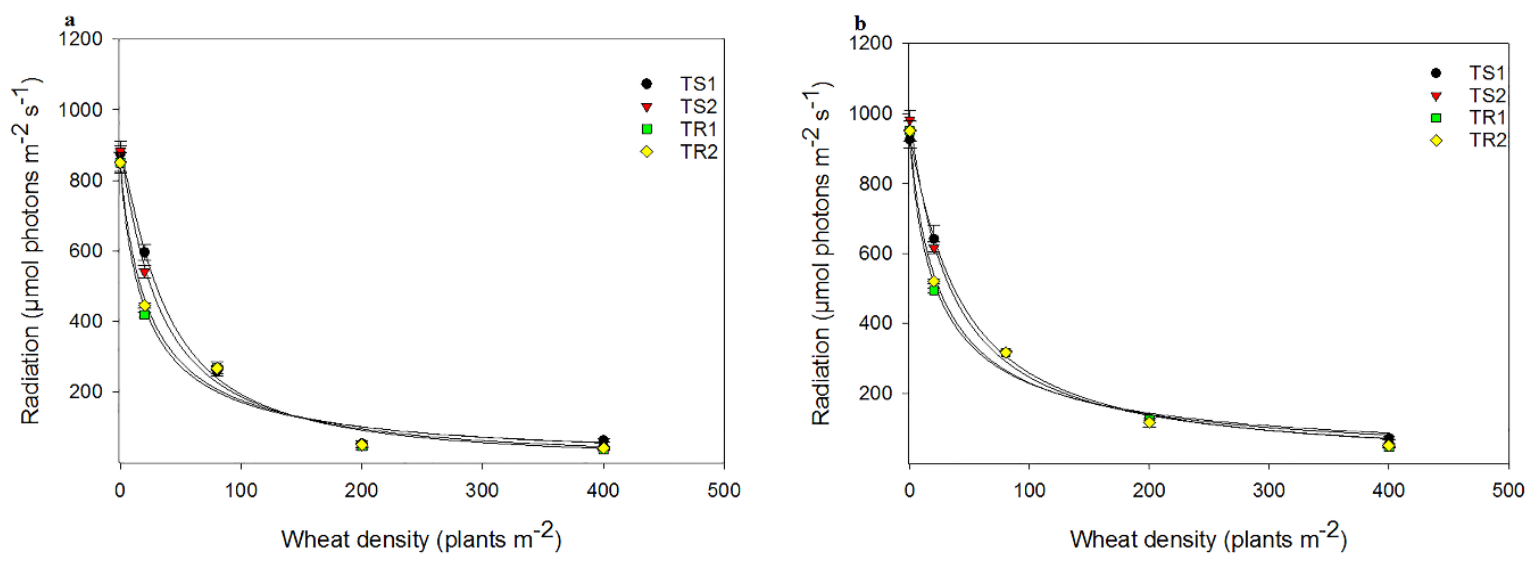

Figure 1. An estimation of photosynthetically active radiation $\left(\mu \mathrm{mol} \mathrm{m}^{-2} \mathrm{~s}^{-1}\right)$ intercepted by the canopy of triazine-resistant (TR) and triazine-susceptible (TS) phenotypes of C. album in the first (a) and second (b) neighbouring plant competition experiments at 35 days after transplanting C. album seedlings.

\section{Discussion}

The fitness of a biotype determines its ability to survive and pass on its genes to successive generations [38]. Under a specific environmental constraint, the individuals that have optimal fitness can adapt to the stressful environment, though this might involve costs (cost of adaptation) [39]. Theoretically, the cost of adaptation associated with resistance to a xenobiotic might make the resistant individuals more vulnerable to other stressors [40].

The cost of adaptation to herbicides in resistant weeds has only been scrutinised for some herbicide-resistant weed species [41]. With resistance to triazines, most of the research has studied just the overall vegetative and reproductive fitness costs for the triazine-resistant weeds [20,31,32,42]. However, a mechanistic interpretation of the cost of adaptation to triazines in the vegetative growth stage of resistant weeds is lacking. Several studies have shown the reproductive fitness penalties associated with triazine resistance $[32,43,44]$. Many management practices predominantly target weeds at their vegetative stage of growth. In this research, we only focused on the vegetative stage to determine if certain parts of this vegetative growth phase had greater fitness costs that could potentially be exploited for managing triazine-resistant $C$. album.

Our results confirmed that the mutation associated with resistance to triazines in C. album also causes fitness penalties, but this occurred mainly at the early vegetative stage of growth and was less noticeable at the later vegetative phase. The triazine-resistant phenotypes accumulated less biomass, were shorter, and had a reduced leaf area than the triazine-susceptible phenotypes at the early vegetative phase (at $35 \mathrm{DAT}$ ), whereas at the later vegetative stage of growth, not all of these differences in growth persist. For instance, a similar value for leaf area was recorded at $55 \mathrm{DAT}$ for both phenotypes.

Among the growth parameters that we evaluated in this research, both the relative growth rate (RGR) and the net assimilation rate (NAR) were found to be significantly reduced in the triazine-resistant phenotypes compared with the triazine-susceptible phenotypes at the early vegetative phase (35 DAT). The greater RGR for the triazine-susceptible phenotype was due to greater NAR rather than the leaf area ratio (LAR), as the LAR was not significantly different between the phenotypes at 35 DAT. Holt et al. [18] suggested that triazine-resistant individuals have a reduction in quantum yield of $\mathrm{CO}_{2}$ possibly due to a reduction in the electron transfer rate. This could explain the lower NAR values for the triazine-resistant phenotypes at the early vegetative phase.

However, at the later vegetative phase, the resistant phenotypes had a significantly higher RGR than the susceptible phenotypes, though there was no significant difference in NAR. At 35 DAT, the resistant plants were on average only $53 \%$ the size of susceptible plants, but by 55 DAT, they were $80 \%$ the size of susceptible plants. The leaf area of resistant plants was significantly smaller than for susceptible plants at 35 DAT, yet there was no significant difference at 55 DAT. 
In these experiments, the triazine-susceptible phenotypes flowered earlier than triazine-resistant ones. Similar results were reported by Darmency and Gasquez [42]. The time for transition from vegetative to flowering stages would occur more rapidly for the plants with a greater RGR [45] which would then reach their maximum height earlier [46]. This could account for the earlier flowering onset recorded for the susceptible phenotypes for which the individuals had a greater RGR at the early vegetative stage of growth and reached their maximum height earlier compared to those of resistant phenotypes.

The triazine-resistant phenotype of $C$. album was found to be shorter than its susceptible counterparts at 35 and 55 DAT; however, both phenotypes acquired similar final plant height at the flowering stage despite the flowering onset occurring at different times. Similarly, Parks et al. [32] recorded greater plant height for the triazine susceptible phenotypes of $C$. album compared to the triazine-resistant ones at the vegetative stage. However, they found a similar final plant height for both phenotypes by maturity, though they did not mention any differences in the time of flowering between triazine-resistant and triazine-susceptible C. album.

The results from this research suggest that the vegetative fitness penalties for triazine-resistant C. album mainly manifests at the early vegetative phase; thus, any management practices to take advantage of this fitness cost should predominantly target the triazine-resistant phenotypes at the early vegetative phase. To this end, agronomic and cultural practices such as the use of more competitive crop cultivars and decreasing row spacing could suppress the growth of triazine-resistant individuals [47,48], but it would be important to ensure the crop established rapidly so that adequate competition would be exerted at the early vegetative phase of the weed. Further investigations are needed to evaluate the effectiveness of such agronomic practices for managing triazine-resistant $C$. album. The lower growth capacity recorded for the triazine-resistant phenotypes at the early vegetative stage of growth could imply that the resistant phenotypes have poorer ability to capture resources under competition thus they are weaker competitors [49]. This was found to be true for the triazine-resistant phenotype of $C$. album in this research, since the triazine-resistant phenotypes were less able to compete with neighbouring plants compared to susceptible ones. Similarly, Vila-Aiub et al. [36] noted that herbicide-resistant individuals with lower vegetative growth rates performed even more poorly during competition for limited environmental resources.

\section{Conclusions}

The fitness penalty associated with pesticide resistance can influence the process of resistance allele stabilization and the dynamics of the pesticide resistance evolution in a population [12]. Evaluating the cost of adaptation can be fruitful when designing herbicide resistance management strategies. This research showed that triazine-resistance in C. album results in some fitness costs which cause lower vegetative growth rates, reductions in leaf area and smaller plant size at the early vegetative phase. We also showed that the fitness cost recorded at the early vegetative stage of growth made the triazine-resistant $C$. album a poorer competitor compared to susceptible individuals. However, the vegetative fitness cost for triazine resistance appeared to fade away gradually in time as almost no fitness costs were recorded for the triazine-resistant phenotypes at the later vegetative stage of growth. Therefore, we postulate that more effective management of triazine-resistant $C$. album can be achieved by applying competitive pressure during the early vegetative phase.

Author Contributions: Conceptualization, H.G. and K.C.H.; Methodology, H.G. and K.C.H.; Investigation, H.G.; Writing-Original Draft Preparation, H.G.; Review and Editing, K.C.H.

Funding: This research received no external funding.

Acknowledgments: The authors wish to thank the staff of the Plant Growth Unit of Massey University for assistance with growing the plants.

Conflicts of Interest: The authors declare no conflict of interest. 


\section{References}

1. Arntzen, C.J.; Pfister, K.; Steinback, K.E. The mechanism of chloroplast triazine resistance: Alteration in the site of herbicide action. In Herbicide Resistance in Plants; LeBaron, H.M., Gressel, J., Eds.; J. Wiley and Sons Inc.: New York, NY, USA, 1982; pp. 185-214.

2. LeBaron, H.M.; McFarland, J.E.; Burnside, O.C. The triazine herbicides: A milestone in the development of weed control technology. In The Triazine Herbicides; LeBaron, H.M., McFarland, J.E., Burnside, O.C., Eds.; Elsevier: San Diego, CA, USA, 2008; pp. 1-12.

3. Ryan, G.F. Resistance of common groundsel to simazine and atrazine. Weed Sci. 1970, 18, 614-616. [CrossRef]

4. Heap, I. The International Survey of Herbicide Resistant Weeds. Available online: http://www.weedscience. com (accessed on 14 March 2019).

5. Devine, M.D.; Shukla, A. Altered target sites as a mechanism of herbicide resistance. Crop Prot. 2000, 19, 881-889. [CrossRef]

6. Ghanizadeh, H.; Harrington, K.C. Non-target site mechanisms of resistance to herbicides. Critic. Rev. Plant Sci. 2017, 36, 24-34. [CrossRef]

7. Anderson, M.P.; Gronwald, J.W. Atrazine resistance in a velvetleaf (Abutilon theophrasti) biotype due to enhanced glutathione S-transferase activity. Plant Physiol. 1991, 96, 104-109. [CrossRef] [PubMed]

8. Patzoldt, W.L.; Dixon, B.S.; Tranel, P.J. Triazine resistance in Amaranthus tuberculatus (Moq) Sauer that is not site-of-action mediated. Pest Manag. Sci. 2003, 59, 1134-1142. [CrossRef] [PubMed]

9. Jasieniuk, M.; Brule-Babel, A.L.; Morrison, I.N. The evolution and genetics of herbicide resistance in weeds. Weed Sci. 1996, 44, 176-193. [CrossRef]

10. Vila-Aiub, M.M.; Neve, P.; Powles, S.B. Fitness costs associated with evolved herbicide resistance alleles in plants. New Phytol. 2009, 184, 751-767. [CrossRef] [PubMed]

11. Ghanizadeh, H.; Harrington, K.C. Perspectives on non-target site mechanisms of herbicide resistance in weedy plant species using evolutionary physiology. AoB Plants 2017, 9, plx035. [CrossRef]

12. Tian, D.; Traw, M.B.; Chen, J.Q.; Kreitman, M.; Bergelson, J. Fitness costs of R-gene-mediated resistance in Arabidopsis thaliana. Nature 2003, 423, 74-77. [CrossRef]

13. Vila-Aiub, M.M.; Neve, P.; Powles, S.B. Resistance cost of a cytochrome P450 herbicide metabolism mechanism but not an ACCase target site mutation in a multiple resistant Lolium rigidum population. New Phytol. 2005, 167, 787-796. [CrossRef]

14. Fernández-Moreno, P.T.; Alcántara-de la Cruz, R.; Smeda, R.J.; De Prado, R. Differential resistance mechanisms to glyphosate result in fitness cost for Lolium perenne and L. multiflorum. Front. Plant Sci. 2017, 8, 1796. [CrossRef] [PubMed]

15. Ghanizadeh, H.; Harrington, K.C. Fitness costs associated with multiple resistance to dicamba and atrazine in Chenopodium album. Planta 2019, 249, 787-797. [CrossRef] [PubMed]

16. Babineau, M.; Mathiassen, S.K.; Kristensen, M.; Kudsk, P. Fitness of ALS-inhibitors herbicide resistant population of loose silky bentgrass (Apera spica-venti). Front. Plant Sci. 2017, 8, 1660. [CrossRef] [PubMed]

17. Conard, S.G.; Radosevich, S.R. Ecological fitness of Senecio vulgaris and Amaranthus retroflexus biotypes susciptible or resistant to atrazine. J. App. Ecol. 1979, 16, 171-177. [CrossRef]

18. Holt, J.S.; Stemler, A.J.; Radosevich, S.R. Differential light responses of photosynthesis by triazine-resistant and triazine-susceptible Senecio vulgaris Biotypes. Plant Physiol. 1981, 67, 744-748. [CrossRef] [PubMed]

19. Weaver, S.E.; Warwick, S.I. Competitive relationships between atrazine resistant and susceptible populations of Amaranthus retroflexus and A. powellii from southern Ontario. New Phytol. 1982, 92, 131-139. [CrossRef]

20. Holt, J.S. Reduced growth, competitiveness, and photosynthetic efficiency of triazine-resistant Senecio vulgaris from California. J. App. Ecol. 1988, 25, 307-318. [CrossRef]

21. Kremer, E.; Kropff, M.J. Comparative growth of triazine-susceptible and -resistant biotypes of Solanum nigrum at different light levels. Ann. Bot. 1999, 83, 637-644. [CrossRef]

22. Frenkel, E.; Matzrafi, M.; Rubin, B.; Peleg, Z. Effects of environmental conditions on the fitness penalty in herbicide resistant Brachypodium hybridum. Front. Plant Sci. 2017, 8, 94. [CrossRef]

23. Conn, J.S.; Thomas, D.L. Common lambsquarters (Chenopodium album) interference in spring barley. Weed Technol. 1987, 1, 312-313. [CrossRef] 
24. Schweizer, E.E. Common lambsquarters (Chenopodium album) interference in sugarbeets (Beta vulgaris). Weed Sci. 1983, 31, 5-8. [CrossRef]

25. Fischer, D.W.; Harvey, R.G.; Bauman, T.T.; Phillips, S.; Hart, S.E.; Johnson, G.A.; Kells, J.J.; Westra, P.; Lindquist, J. Common lambsquarters (Chenopodium album) interference with corn across the northcentral United States. Weed Sci. 2004, 52, 1034-1038. [CrossRef]

26. Ghanizadeh, H.; Harrington, K.C. Cross-resistance to auxinic herbicides in dicamba-resistant Chenopodium album. N. Z. J. Agric. Res. 2017, 60, 45-53. [CrossRef]

27. Rahman, A. Current status of herbicide resistance in New Zealand weeds. In Proceedings of the 9th Australian Weeds Conference, Adelaide, Australia, 6-10 August 1990; pp. 196-200.

28. Ghanizadeh, H.; Harrington, K.C.; James, T.K. A comparison of dicamba absorption, translocation and metabolism in Chenopodium album populations resistant and susceptible to dicamba. Crop Prot. 2018, 110, 112-116. [CrossRef]

29. Rahman, A.; James, T.; Trolove, M. Characteristics and control of dicamba-resistant common lambsquarters (Chenopodium album). Weed Biol. Manag. 2014, 14, 88-98. [CrossRef]

30. Ghanizadeh, H.; Harrington, K.C.; James, T.K.; Woolley, D.J. A quick test using seeds for detecting dicamba resistance in fathen (Chenopodium album). Aus. J. Crop. Sci. 2015, 9, 337-343.

31. Warwick, S.I.; Black, L. The relative competitiveness of atrazine susceptible and resistant populations of Chenopodium album and C. strictum. Can. J. Bot. 1981, 59, 689-693. [CrossRef]

32. Parks, R.J.; Curran, W.S.; Roth, G.W.; Hartwig, N.L.; Calvin, D.D. Herbicide susceptibility and biological fitness of triazine-resistant and susceptible common lambsquarters (Chenopodium album). Weed Sci. 1996, 44, 517-522. [CrossRef]

33. Ghanizadeh, H. Aspects of Herbicide Resistance in Three New Zealand Weed Species. Ph.D. Thesis, Massey University, Palmerston North, New Zealand, 2015; p. 233.

34. Hunt, R.; Causton, D.R.; Shipley, B.; Askew, A.P. A modern tool for classical plant growth analysis. Ann. Bot. 2002, 90, 485-488. [CrossRef]

35. Weiner, J. A neighborhood model of annual-plant interference. Ecology 1982, 63, 1237-1241. [CrossRef]

36. Vila-Aiub, M.M.; Neve, P.; Powles, S.B. Evidence for an ecological cost of enhanced herbicide metabolism in Lolium rigidum. J. Ecol. 2009, 97, 772-780. [CrossRef]

37. R Core Team. R: A Language and Environment for Statistical Computing; R Foundation for Statistical Computing: Vienna, Austria, 2017.

38. Orr, H.A. Fitness and its role in evolutionary genetics. Nat. Rev. Genet. 2009, 10, 531-539. [CrossRef] [PubMed]

39. Purrington, C.B. Costs of resistance. Curr. Opin. Plant Biol. 2000, 3, 305-308. [CrossRef]

40. Bergelson, J.; Purrington, C.B.; Palm, C.J.; Lopez-Gutierrez, J.C. Cost of resistance: A test using transgenic Arabidopsis thaliana. Proc. Natl. Acad. Sci. USA 1996, 263, 1659-1663.

41. Vila-Aiub, M.M.; Gundel, P.E.; Preston, C. Experimental methods for estimation of plant fitness costs associated with herbicide-resistance genes. Weed Sci. 2015, 63, 203-216. [CrossRef]

42. Darmency, H.; Gasquez, J. Appearance and spread of triazine resistance in common lambsquarters (Chenopodium album). Weed Technol. 1990, 4, 173-177. [CrossRef]

43. Williams, M.M., II; Jordan, N.; Yerkes, C. The fitness cost of triazine resistance in jimsonweed (Datura stramonium L.). Am. Midl. Nat. 1995, 133, 131-137.

44. Warwick, S.I.; Black, L.D. Relative fitness of herbicide-resistant and susceptible biotypes of weeds. Phytoprotection 1994, 75, 37-49. [CrossRef]

45. Poorter, $\mathrm{H}$. Interspecific variation in relative growth rate: On ecological causes and physiological consequences. In Causes and Consequences of Variation in Growth Rate and Productivity of Higher Plants; Lambers, H., Ed.; SPB Academic Publishing: The Hague, The Netherlands, 1989; pp. 45-69.

46. Sun, S.; Frelich, L.E. Flowering phenology and height growth pattern are associated with maximum plant height, relative growth rate and stem tissue mass density in herbaceous grassland species. J. Ecol. 2011, 99, 991-1000. [CrossRef]

47. Ghanizadeh, H.; Harrington, K.C. Weed management in New Zealand pastures. Agronomy 2019, 9, 448. [CrossRef] 
48. Jordan, N.; Kelrick, M.; Brooks, J.; Kinerk, W. Biorational management tactics to select against triazine-resistant Amaranthus hybridus: A field trial. J. App. Ecol. 1999, 36, 123-132. [CrossRef]

49. Goldberg, D.E. Components of resource competition in plant communities. In Perspectives in Plant Competition; Grace, J.B., Tilman, D., Eds.; Academic Press: San Diego, CA, USA, 1990.

(C) 2019 by the authors. Licensee MDPI, Basel, Switzerland. This article is an open access article distributed under the terms and conditions of the Creative Commons Attribution (CC BY) license (http://creativecommons.org/licenses/by/4.0/). 